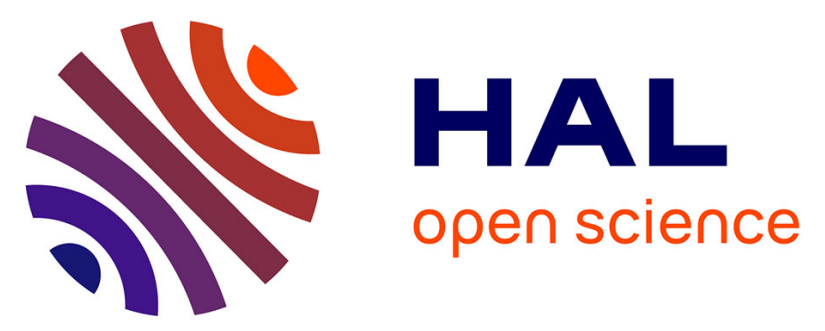

\title{
On the flexural behaviour of GFRP beams obtained by bonding simple panels: an experimental investigation
}

Francesco Ascione, Geminiano Mancusi, Saverio Spadea, Marco Lamberti, Frédéric Lebon, Aurelien Maurel-Pantel

\section{- To cite this version:}

Francesco Ascione, Geminiano Mancusi, Saverio Spadea, Marco Lamberti, Frédéric Lebon, et al.. On the flexural behaviour of GFRP beams obtained by bonding simple panels: an experimental investigation. Composite Structures, 2015, 131, pp.55-65. 10.1016/j.compstruct.2015.04.039 . hal01247913

\section{HAL Id: hal-01247913 \\ https://hal.science/hal-01247913}

Submitted on 30 May 2018

HAL is a multi-disciplinary open access archive for the deposit and dissemination of scientific research documents, whether they are published or not. The documents may come from teaching and research institutions in France or abroad, or from public or private research centers.
L'archive ouverte pluridisciplinaire HAL, est destinée au dépôt et à la diffusion de documents scientifiques de niveau recherche, publiés ou non, émanant des établissements d'enseignement et de recherche français ou étrangers, des laboratoires publics ou privés. 


\title{
On the flexural behaviour of GFRP beams obtained by bonding simple panels: An experimental investigation
}

\author{
Francesco Ascione ${ }^{\mathrm{a}, *}$, Geminiano Mancusi ${ }^{\mathrm{a}}$, Saverio Spadea ${ }^{\mathrm{a}}$, Marco Lamberti ${ }^{\mathrm{a}}$, Fréderic Lebon ${ }^{\mathrm{b}}$, \\ Aurélien Maurel-Pantel ${ }^{\mathrm{b}}$ \\ a Department of Civil Engineering, University of Salerno, Via Giovanni Paolo II 132, 84084 Fisciano, SA, Italy \\ ${ }^{\mathrm{b}}$ LMA, Aix-Marseille University, CNRS, UPR 7051, Centrale Marseille, F-13402 Marseille Cedex 20, France
}

\begin{abstract}
This paper presents some experimental results dealing with the mechanical performance of composite beams obtained by bonding Glass Fibre Reinforced Polymer (GFRP) rectangular pultruded panels by means of an epoxy structural adhesive. The flexural response of these bonded beams was compared with those obtained by the pultrusion process with the same geometrical and material properties. As a matter of fact, no significant loss of performance emerged in terms of failure load; moreover, an increase of pre-failure stiffness was observed. This result may allow us to consider bonded GFRP beams as a viable simplification within the field of composite structures.
\end{abstract}

\section{Introduction}

Although traditional materials (steel, concrete, timber and masonry) still dominate the building industry, new materials are constantly being explored by engineers and scientists. For instance, the use of the so-called FRPs (Fibre-Reinforced Polymers) is gradually spreading worldwide. FRPs can be qualified as non-corrosive, high mechanical strength and lightweight materials. They have achieved in the last few years a relevant role as a building material for applications such as flexural and shear strengthening, column confinement, cables, stands, truss members, footbridges, boardwalks, high voltage electricity poles, small buildings and emergency-oriented solutions [1-3]. The main idea of FRPs is the combination, on a macroscopic scale, of two different long continuous fibres and a polymeric resin. More specifically, high strength fibres (glass, carbon, aramid or ultra-thin steel wires) provide strength and stiffness while the resin (polyester, vinylester or epoxy) protects the fibres and guarantees the stress transfer between them. As a result, enhanced final properties are obtained with respect to those exhibited by the individual constituents.

Glass Fibre Reinforced Polymers (GFRP) are widely used due to their relatively low cost, although glass fibres exhibit much lower elastic modulus and ultimate strength than carbon fibres. In addition, some additional issues emerge with regard to durability in

\footnotetext{
* Corresponding author.

E-mail address: fascione@unisa.it (F. Ascione).
}

alkaline environments and long-term response under sustained stresses $[4,5]$.

Examples of applications of FRPs are numerous [6,7]. The first buildings made from FRP profiles were single-storey gable frames used in the electronics industry for Electromagnetic Interference (EMI) test laboratories. A five-storey building, named the Eyecatcher Building was erected for the Swiss Building Fair in 1998. Another example is the $38 \mathrm{~m}$ span Lleida Footbridge in Spain, consisting of a double-tied arch crossing an existing roadway and a high-speed railway line. The arches and the tied longitudinal bridge deck girders were made of a rectangular hollow FRP cross-section obtained from two U-profiles joined together with two bonded flat plates to form the rectangular tubular section. This application reflects exactly the idea upon which the experimental investigation presented in this paper is based. Advanced applications of FRP composite tubes can be found mainly in North America, where hybrid configurations of FRP/lightweight concrete have been proposed for arch members. Furthermore, composite piles have also been proposed for marine installations.

The most cost-effective way of producing FRPs is the automated process of pultrusion. This process optimises the production of bars and thin/thick-walled profiles with both closed and open cross-sections which are constant over the length. Examples are I-, L-, H- and tubular profiles. The European Standard UNI EN 13706:2002 [8] provides many specifications for pultruded profiles. Because the industrial process is optimised for mass pultrusion of a limited number of shapes, it is difficult to produce complex shapes with standard cost targets. A low-cost design 
strategy inspired by modularity, able to exploit the immediate availability of "ready-to-use" standard components, plays a crucial role for the large-scale viability of FRP structures. The idea discussed in this paper is focused exactly on the possibility of achieving a complex FRP shape by bonding an appropriate number of simple pultruded shapes with a common epoxy glue. For example, a generic I-profile may be obtained by bonding three rectangular panels (the top/bottom flanges and the web panel), rather than via a unique pultrusion application. In addition, web-to-flange junctions may also be strengthened by bonding appropriate angle profiles. In this view, the possibility of considering composite profiles of a generic cross-section from simple rectangular panels would be an interesting constructive simplification.

The aim of this study is to answer the following two questions.

The first is "what performance level can be achieved for bonded composite beams compared to similar pultruded ones?". From a mechanical point of view, both FRP pultruded beams and bonded ones can be considered as linear elastic, homogeneous and transversely isotropic, with the plane of isotropy being normal to the longitudinal axis (i.e. the axis of pultrusion) [9,10]. Moreover, the mechanical behaviour of pultruded profiles, especially in the case of open profiles, is highly affected by warping strains as well as shear deformations [11]. Finally, the low values of the shear moduli (more or less the same as polymeric resin), coupled with the time-dependent nature of the mechanical behaviour, can cause non-negligible increases in lateral deflections, thus affecting both the local and global buckling loads [12-14]. As a consequence, FRP beams exhibit a complex behaviour related to a multi-interaction between shear deformability, warping, non-uniform torsional rigidity and creep. Other topics in the literature deal with possible rotations and/or sliding at panel-to-panel interfaces [15-17]. A possible consequence is the decrease of the flexural stiffness. The second question is: "can this loss of stiffness affect the pre-failure response and the failure loads of bonded beams?".

Even though many efforts have been made to study the behaviour of full-FRP structures from the numerical and theoretical point of view, the experimental findings available in the literature on this topic are still very limited $[18,19]$. For this reason, the authors have recently initiated a large experimental investigation, still under development, in order to compare the flexural behaviour of pultruded FRP profiles with that of bonded FRP profiles. The results have shown the possibility of achieving a very good performance, in terms of both failure load and flexural stiffness, allowing us to consider the bonding system proposed as highly competitive in the field of construction of pultruded profiles.

\section{Experimental procedures}

\subsection{Materials}

The experimental investigation presented in this paper deals with four point bending tests performed on Glass FRP beams. More specifically, the flexural behaviour of two different groups of beams was investigated:

- Type 1 (pultruded I-beams) entirely manufactured by the pultrusion process;

- Type 2 (bonded I-beams) obtained by bonding simple rectangular pultruded panels.

In both cases the E-glass G967P reinforcement is considered, with a volume fraction of $60 \%$, whereas the remaining volume is made of an isophalic polyester P4506 Firereta matrix. The colour is light grey RAL 7035 with a veil surface. As concerns the bonding of simple panels (Type 2 beams), the structural adhesive adopted is Sikadur-30 provided by Sika Ltd.
More detailed information about the above-mentioned beams is presented in the next two sections.

\subsubsection{Pultruded I-beams (Type 1)}

These beams were obtained entirely by the pultrusion process. The cross-section shape is depicted in Figs. 1a and $1 \mathrm{~b}$, and the geometrical dimensions and mechanical properties are reported in Table 1 , as declared by the producer. A total of four pultruded I-beams were considered in this study.

\subsubsection{Bonded I-beams (Type 2)}

These beams were created by bonding three simple pultruded panels. It is important to underline that the final shape is essentially the same as that of the previous beams (Type 1 beams), except for the rounded web-flange zones. The cross-section shape is depicted in Figs. $2 \mathrm{a}$ and $2 \mathrm{~b}$ and the geometrical and mechanical properties are reported in Table 2.

\subsubsection{Preparation of the bonded beams (Type 2)}

The bonded beams were manufactured in three steps.

The first step deals with the preparation of all components (cleaning and measuring).

Next, the bonding of the first flange to the web panel (Fig. 3a) is carried out (Step 2). The bonding procedure was assisted by temporary constraints provided by two lateral steel angle profiles (Fig. 3c), aimed to ensure the orthogonality between the two panels. At this stage, careful control of the adhesive thickness was also performed.

After $24 \mathrm{~h}$, the other flange was bonded (Fig. 3b) at the opposite side, according to the same sequence described above (Step 3 ).

A total of six bonded I-beams were assembled, four of which were further strengthened by adding an adhesive curb (Sikadur-30) at the web-flange junction on both the left and right sides, as shown in Figs. 4a and $4 \mathrm{~b}$.

The dimensions of the curb were $10 \mathrm{~mm} \times 10 \mathrm{~mm}$ over the full length of the beam $(1400 \mathrm{~mm})$. The main idea was to simulate the role played by the rounded web-flange zones in pultruded beams (Fig. 5).

Type 2 beams were cured over 7 days, with the room temperature kept constant at a value falling in the range indicated by the Sikadur-30 datasheet $\left(15^{\circ} \mathrm{C}-30^{\circ} \mathrm{C}\right)$.

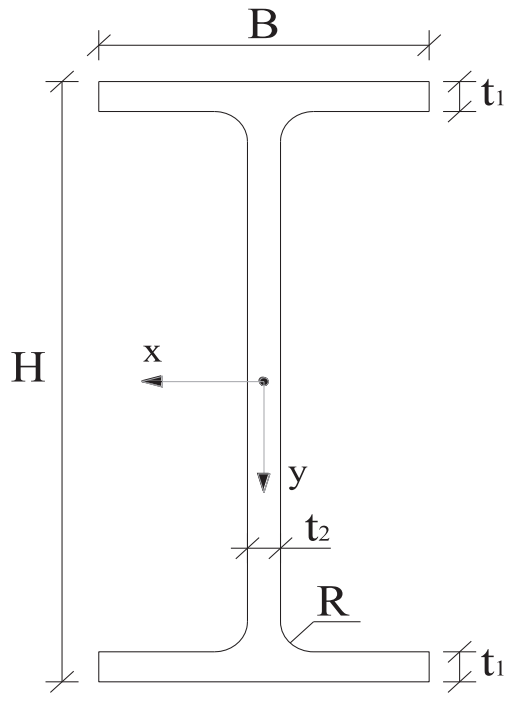

Fig. 1a. Type 1 beam - cross-section. 


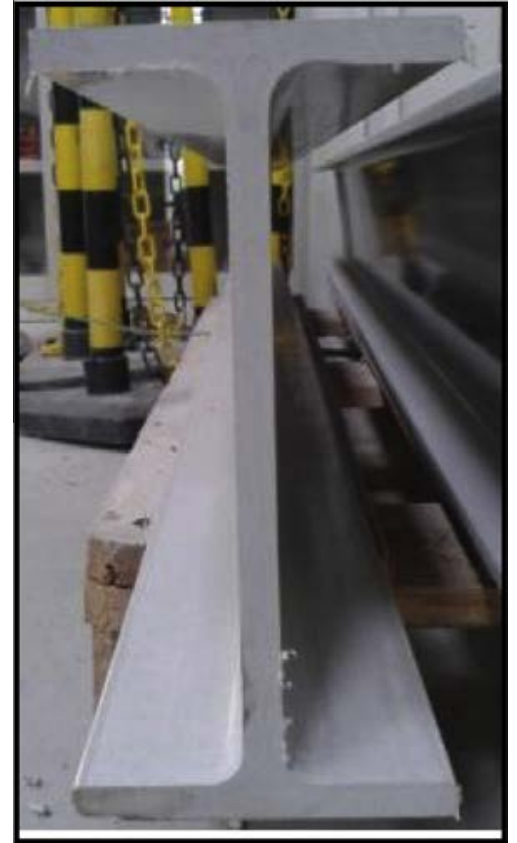

Fig. 1b. Type 1 beam - photo.

Table 1

Pultruded beam (Type 1) properties provided by the producer.

\begin{tabular}{lllr}
\hline Cross-section shape & $I$ & & \\
\hline Geometrical dimensions & & Measure unit & Value \\
Flange width & $B$ & $\mathrm{~mm}$ & 100 \\
Height & $H$ & $\mathrm{~mm}$ & 200 \\
Flange thickness & $t_{1}$ & $\mathrm{~mm}$ & 10 \\
Web thickness & $t_{2}$ & $\mathrm{~mm}$ & 10 \\
Radius & $R$ & $\mathrm{~mm}$ & 10 \\
Mechanical properties & & & \\
Young's modulus of elasticity & $E_{0^{\circ}}$ & $\mathrm{MPa}$ & 28000 \\
Shear modulus of elasticity & $G_{x z}, G_{y z}$ & $\mathrm{MPa}$ & 3000 \\
Flexural strength & $\mathrm{MPa}$ & 240 \\
Tensile strength & $f_{b, 0^{\circ}}$ & $\mathrm{MPa}$ & 240 \\
Compressive strength $^{\mathrm{a}}$ & $f_{t, 0^{\circ}}$ & $\mathrm{MPa}$ & 240 \\
Shear strength $^{\mathrm{a}}$ & $f_{c, 0^{\circ}}$ & $\mathrm{MPa}$ & 25 \\
\hline
\end{tabular}

a Pulling direction during pultrusion process (axis of pultrusion).

\subsection{Experimental set-up}

Four-point bending tests were carried out at the Materials and Structural Testing Laboratory of the University of Salerno, by means of a $3000 \mathrm{kN}$ universal testing machine (ITALSIGMA IT2005-026 - frequency range up to $1.0 \mathrm{~Hz}$ - maximum displacement $\pm 75 \mathrm{~mm}$ ) equipped with a load cell. The vertical load was applied on the simply supported beam by means of a steel frame, connected to the vertical jack of the testing machine as shown in Fig. 6b. The steel frame permitted us to apply the two active loads at a distance equal to $L / 4$ from the supports $(L=1180 \mathrm{~mm})$, as shown in Fig. 6.

Quasi-static tests were performed according to a displacement control modality at a constant rate of $5 \mu \mathrm{m} / \mathrm{s}(0.3 \mathrm{~mm} / \mathrm{min})$.

The mechanical response of each specimen was monitored by:

- ten uniaxial self-compensated strain gauges (SG), model "Vishay MM C2A-06-125LW-120";

- four Linear Variable Differential Transducers (LVDT), measuring range $0-50 \mathrm{~mm}$, resolution $1 \mu \mathrm{m}$;

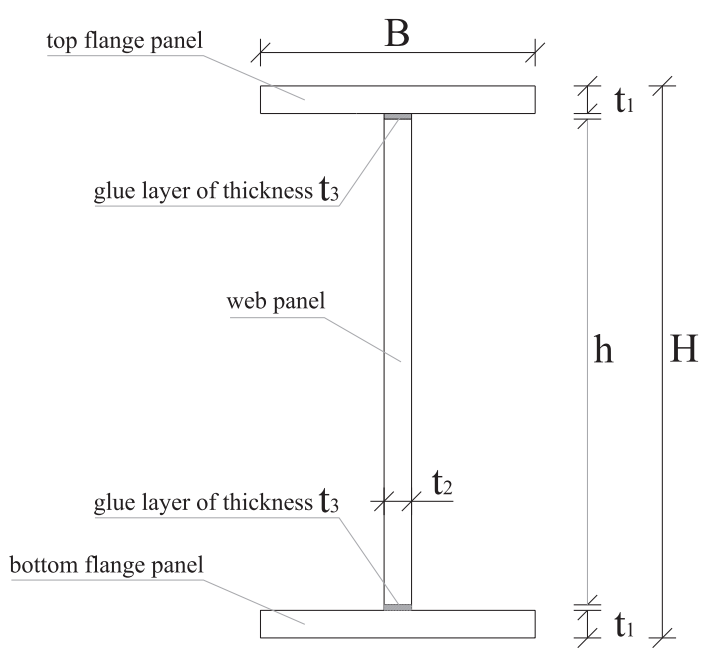

Fig. 2a. Type 2 beam - cross-section.

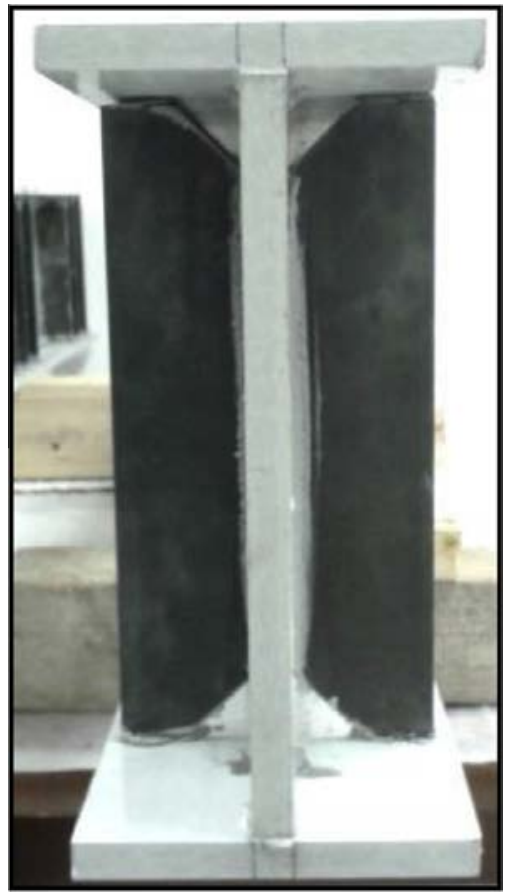

Fig. 2b. Type 2 beam- photo.

Table 2

Bonded beam (Type 2)

\begin{tabular}{|c|c|c|c|}
\hline Cross-section shape & $I$ & & \\
\hline $\begin{array}{l}\text { Geometrical dimensions (measured by the } \\
\text { authors) }\end{array}$ & & $\begin{array}{l}\text { Measure } \\
\text { unit }\end{array}$ & Value \\
\hline Flange panels width & $B$ & $\mathrm{~mm}$ & 100 \\
\hline Web panels height & $h$ & $\mathrm{~mm}$ & 176 \\
\hline Flange panels thickness & $t_{1}$ & $\mathrm{~mm}$ & 10 \\
\hline Web panels thickness & $t_{2}$ & $\mathrm{~mm}$ & 10 \\
\hline Radius & $R$ & $\mathrm{~mm}$ & 10 \\
\hline Glue thickness & $t_{3}$ & $\mathrm{~mm}$ & 2 \\
\hline Whole cross-section height & $H$ & $\mathrm{~mm}$ & 200 \\
\hline \multicolumn{4}{|c|}{ Simple panels mechanical properties (provided by the producer) } \\
\hline Young's modulus of elasticity & $E_{0^{\circ}}$ & $\mathrm{MPa}$ & 28000 \\
\hline Shear modulus of elasticity & $\begin{array}{l}G_{x z} \\
G_{y z}\end{array}$ & $\mathrm{MPa}$ & 3000 \\
\hline
\end{tabular}

${ }^{\text {a }}$ Pulling direction during pultrusion process (axis of pultrusion). 


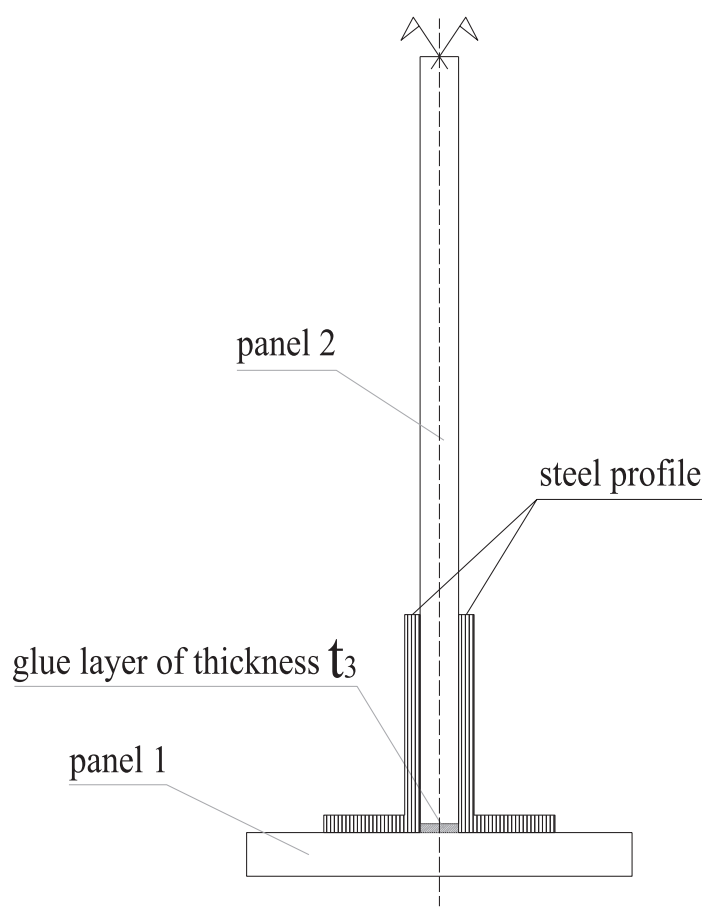

Fig. 3a. Type 2 beam - step 2 .

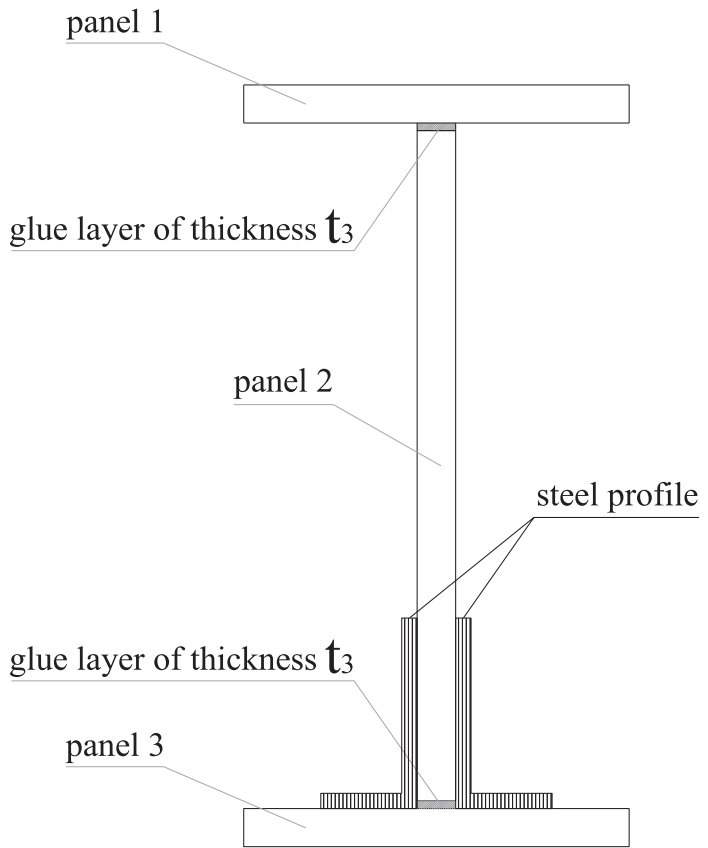

Fig. 3b. Type 2 beam - step 3 .

- two Laser Transducers (LT), measuring range 0-100 mm, resolution $1 \mu \mathrm{m}$.

In detail, the strain gauges SG were bonded at the mid-span cross-section: SG1, SG2 and SG3 were bonded on the top side of the upper flange, SG4, SG5 and SG6 at the bottom side of the lower flange, while SG7 and SG9 as well as SG8 and SG10 were bonded on both sides of the web (Fig. 7b).

The above-described instrumentation was introduced with the following purposes:

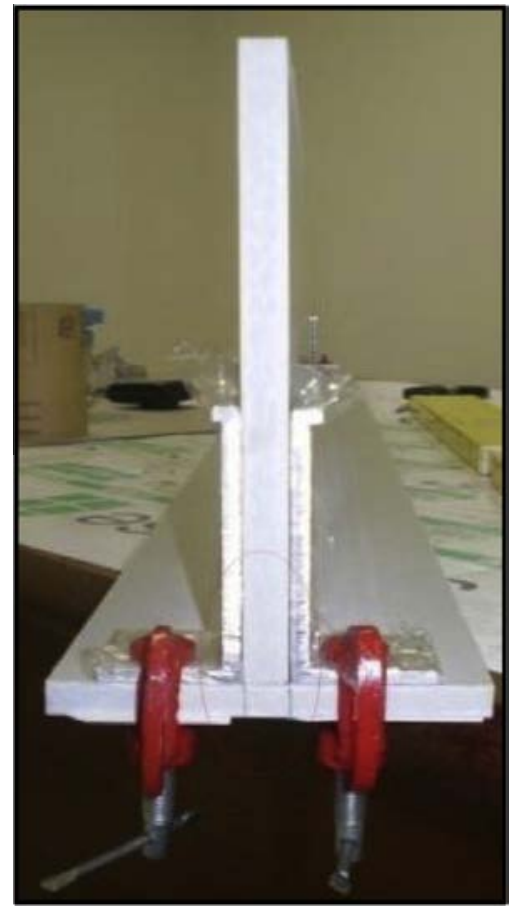

Fig. 3c. Type 2 beam - steel angle profiles (photo).

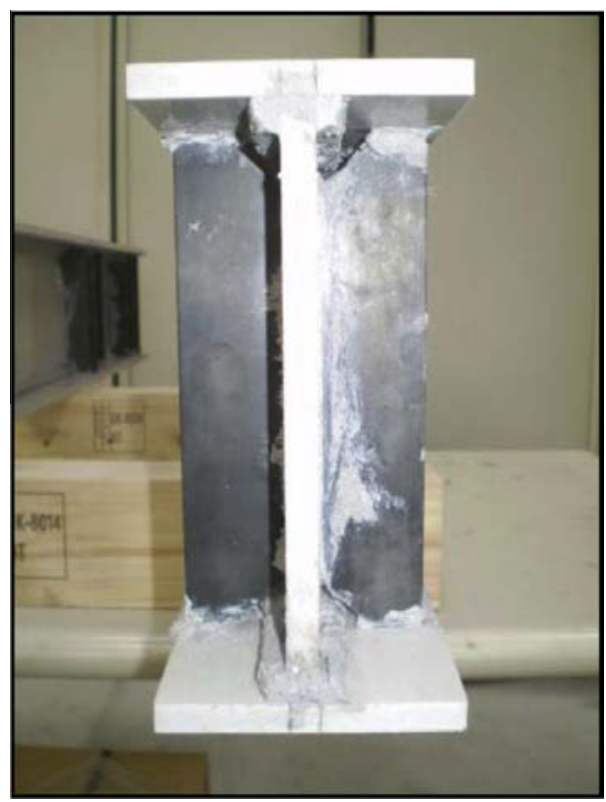

Fig. 4a. Web-flange reinforcement - cross end view.

- six strain gauges (from SG1 to SG6) were utilised to evaluate the flexural curvature of the whole cross-section (global curvature);

- four strain gauges (from SG7 to SG10) were utilised to evaluate the flexural curvature of the web panel (local curvature);

- the four vertical LVDTs were utilised to evaluate the deflections of the beam at different positions over its length (Fig. 7a);

- the two laser transducers were appointed on a transversal rigid bar mounted on the mid-span of the beam, in order to evaluate the torsional rotation of the cross-section (Fig. 7c).

In order to prevent stress concentrations and consequently undesirable local cracks, the following devices were placed at the location of both active and reactive forces: 


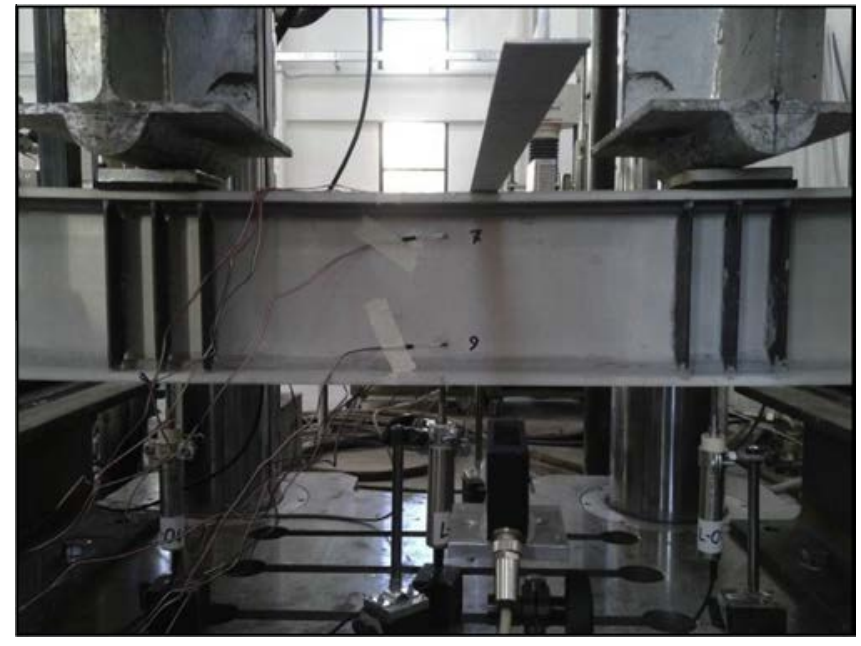

Fig. 4b. Web-flange reinforcement - frontal view.

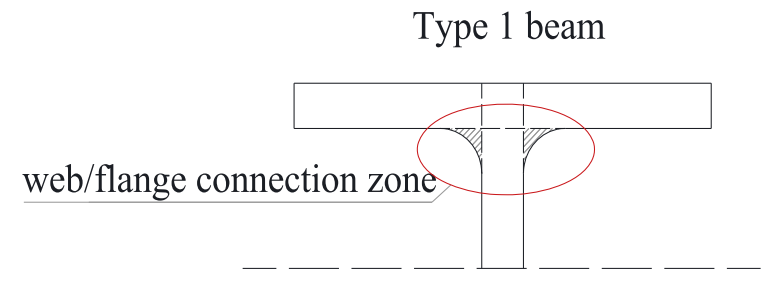

Type 2 beam

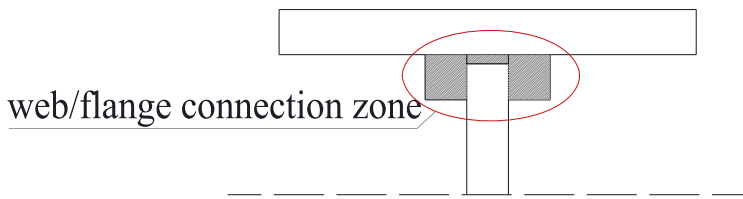

Fig. 5. Web-flange connection zone in Type 1 and Type 2 beams.

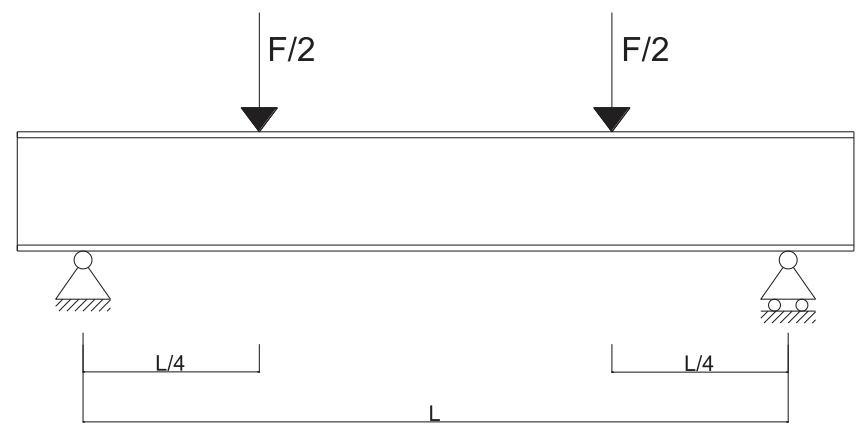

Fig. 6a. Static scheme.

- a neoprene pad (with thickness equal to $10 \mathrm{~mm}$ ) in contact with the beam surface;

- a $100 \mathrm{~mm} \times 100 \mathrm{~mm} \times 10 \mathrm{~mm}$ steel plate, between the neoprene pads and the steel rounded surfaces of the testing device.

Moreover, appropriate stiffeners (made of three transverse steel plates grouped together) were placed at both sides of the web panel, as shown in Fig. 6b.

The signals given by the load cell, LVDTs, LTs and SGs were recorded by an automatic data acquisition system (System 5100 Vishay MM) with a frequency equal to 10 data per second.

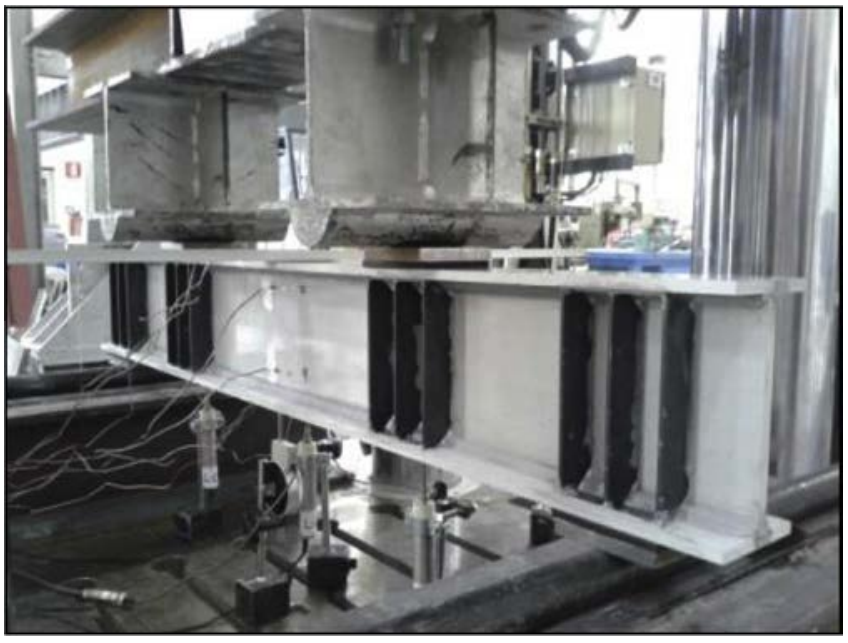

Fig. 6b. Load condition.

\section{Results and discussion}

In this section the experimental results of the ten point bending tests performed on Type 1 beams (four tests) and Type 2 beams (six tests) are reported.

The results were post-processed in view of evaluating the failure load, the Young's modulus, the bending curvature and the flexural mid-span deflection as discussed in the following.

In particular, Figs. 8 shows the load vs mid-span flexural deflection curves reported for all tested specimens. The load $\mathrm{P}$, lying on the vertical axis, is the sum of two vertical forces $(F / 2)$ as shown in Fig. 7a; the deflection, $v$, plotted on the horizontal axis has been evaluated as the mean value of data returned by LVDT1 and LVDT2 (Fig. 7a).

For a better understanding of Figs. 8, a simplified notation has been adopted:

- the $i$ th Type 1 beam is indicated as "T1_i";

- the $i$ th Type 2 beam is indicated as "T2_ $i$ ";

- the ith Type 2 beam strengthened at the web-flange junction is indicated as "T2r $i$ ".

In particular, Fig. 8a refers to four Type 1 beam specimens, while Figs. 8b and 8c refer to six Type 2 beam specimens respectively cured at $15^{\circ} \mathrm{C}$ (three specimens) and $28^{\circ} \mathrm{C}$ (further three specimens).

It is important to remark that the results obtained for beam T1_1 were discarded since local cracks that occurred over the test path compromised its global behaviour. The pultruded beam T1_1 was in fact tested without the interposition of the steel plate between the applied force and the neoprene pad (see Fig. 9).

The results for all tests, in terms of failure load, $P$ (measured in $\mathrm{kN}$ ) and flexural mid-span deflection, $v$ (measured in $\mathrm{mm}$ ) are reported in Table 3. Moreover, the curing temperature adopted during the manufacturing of the bonded beams is indicated in the last column.

Table 4 presents the evaluation of the global flexural curvature, $\theta$, the local flexural curvature of the web, $\theta_{w}$, the Young's modulus, $E$, as well as the flexural mid-span deflection, $v$. Two different load levels were considered: $50 \mathrm{kN}$ and $100 \mathrm{kN}$. The curing temperature is indicated in the last column. Moreover, the strain profiles exhibited by Type 2 beams at mid-span cross-section are shown in Figs. 10a and 10b for both the load levels cited above, respectively.

The Young's modulus, $E$, was evaluated in accordance with the European Standard UNI EN 13706-2 indications, considering the 


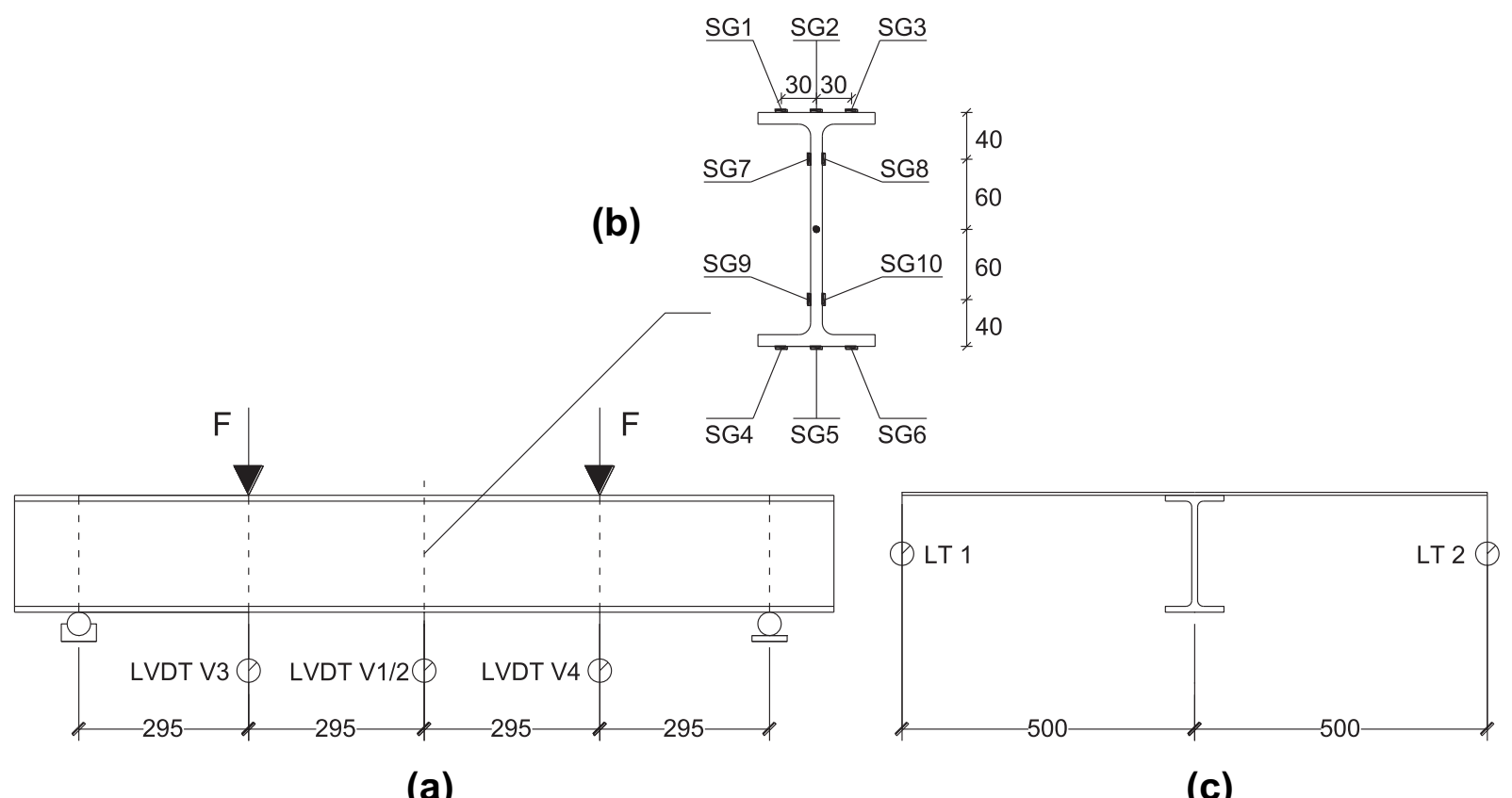

Fig. 7. Instrumentation: (a) LVDTs positioning; (b) SGs positioning; (c) LTs position and rigid arm.

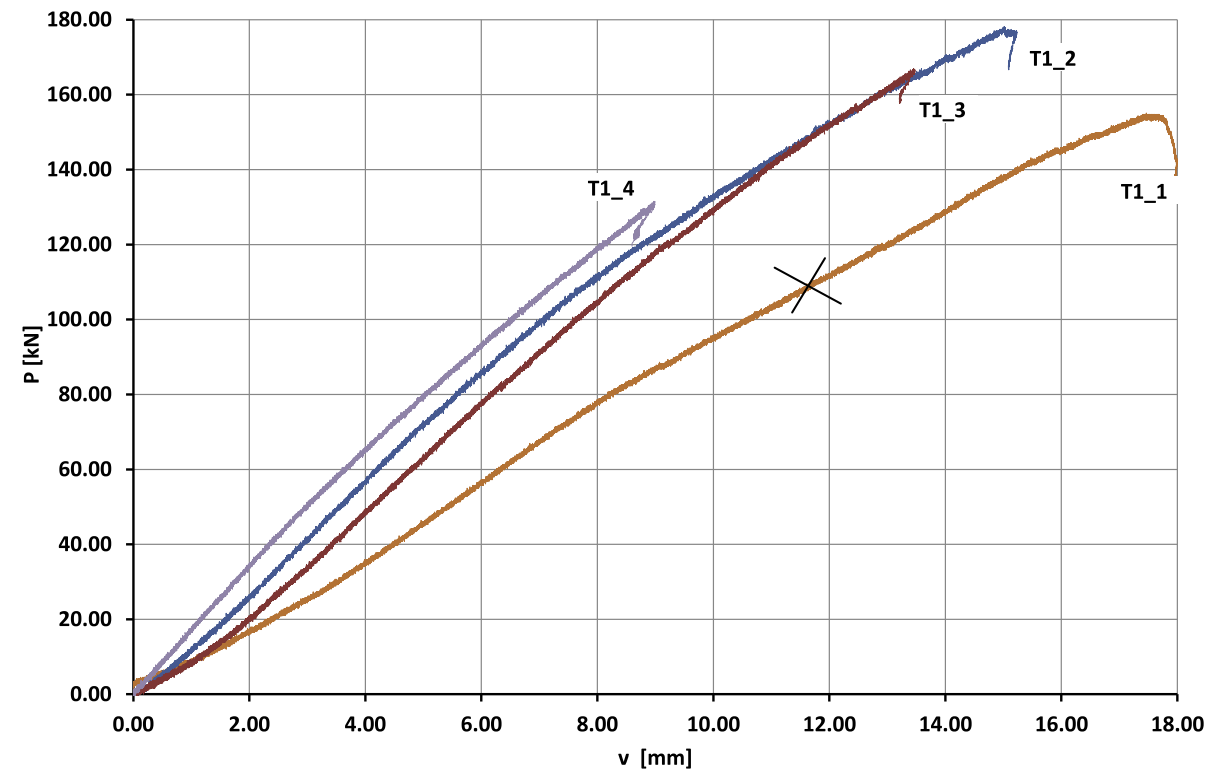

Fig. 8a. Load vs mid-span flexural deflection curve (pultruded beams - T1_1, T1_2, T1_3, T1_4).

following two experimental points of coordinates $\left(v_{1}, P_{1}\right)$ and $\left(v_{2}, P_{2}\right)$ with $v_{1}=L / 500=2.36 \mathrm{~mm}$ and $v_{2}=L / 200=5.90 \mathrm{~mm}$. The final formula is as follows:

$E=\alpha \frac{L^{3}}{I} \frac{\left(P_{2}-P_{1}\right)}{\left(v_{2}-v_{1}\right)}$ with $\alpha \approx \frac{15}{384}$

In Eq. (1), $P_{1}=P_{1}\left(v_{1}\right)$ and $P_{2}=P_{2}\left(v_{2}\right)$ are the loads corresponding to the flexural mid-span deflections $v_{1}$ and $v_{2}$, respectively; the symbol $I$ denotes the second moment of area of the profile. Coefficient $\alpha$ refers to shear deformability according to the Timoshenko beam model and depends on the static scheme considered.
The results reported in Tables 3 and 4 and Fig. 10 allow the following remarks:

- Type 1 beams (pultruded) show a substantially linear response up to failure, as expected; on the contrary, Type 2 beams (bonded) clearly show a non-linear behaviour, with constant loss of stiffness as the load increases.

- The mechanical response of the Type 2 beams is significantly influenced by the curing temperature of the bonding interfaces. With reference to the $100 \mathrm{kN}$ load level, the Young's modulus increases from $18254 \mathrm{MPa}$ (T2r_2) to $22411 \mathrm{MPa}$ (T2r_5) and consequently the deflection decreases from $7.453 \mathrm{~mm}$ to $5.501 \mathrm{~mm}$. 


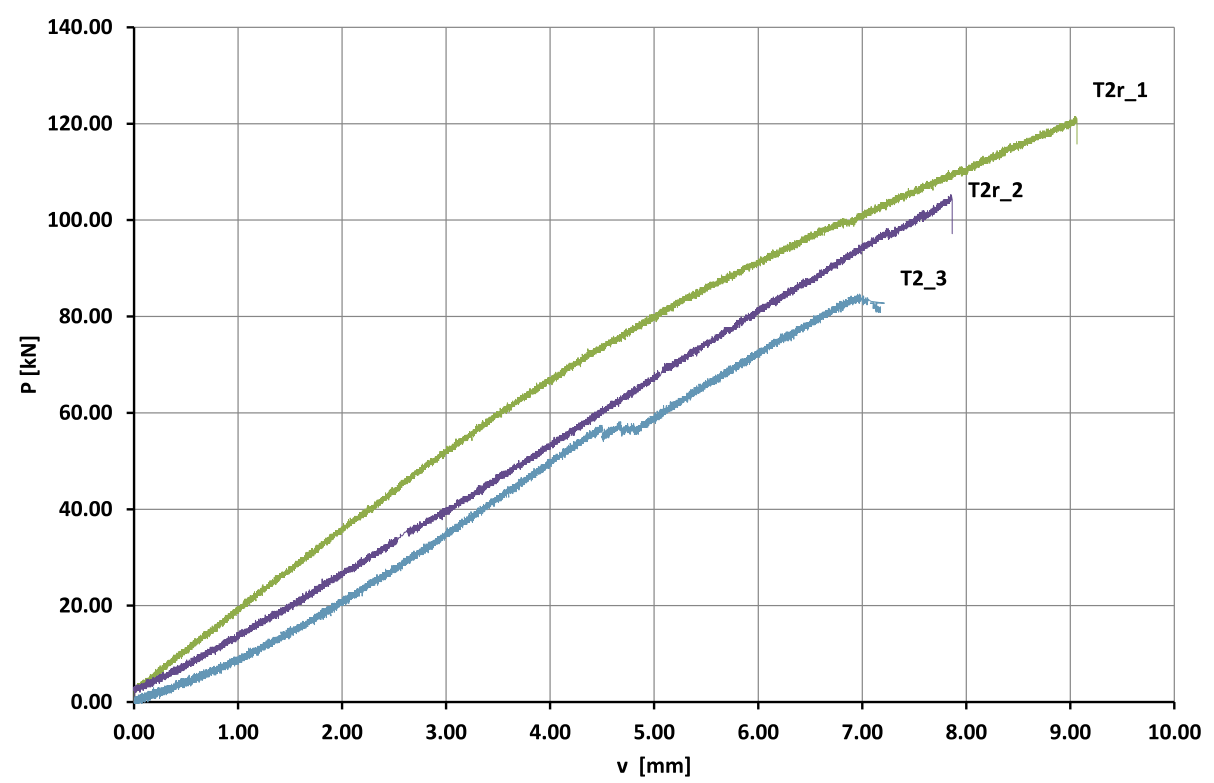

Fig. 8b. Load vs mid-span flexural deflection curve (bonded beams with curing temperature $15{ }^{\circ} \mathrm{C}-\mathrm{T} 2 \mathrm{r}_{-} 1, \mathrm{~T} 2 \mathrm{r} \_2, \mathrm{~T} 2 \_3$ ).

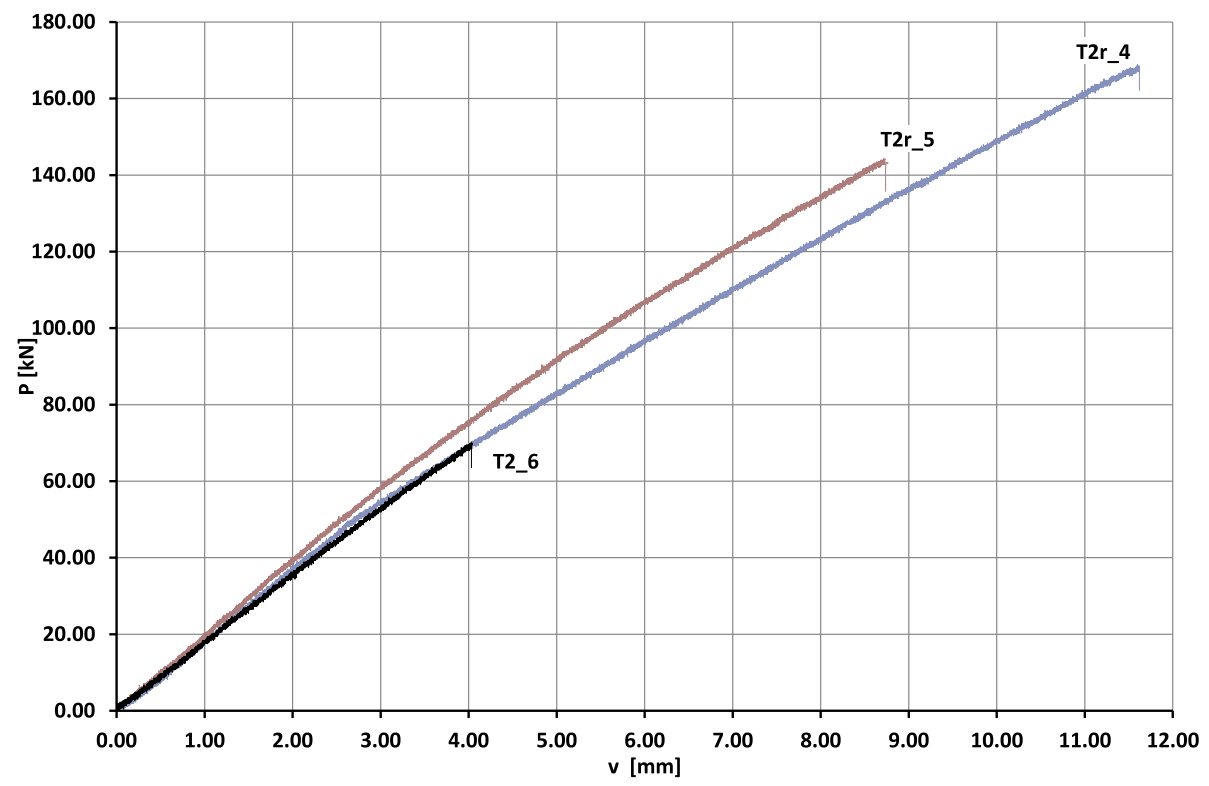

Fig. 8c. Load vs mid-span flexural deflection curve (bonded beams with curing temperature $28{ }^{\circ} \mathrm{C}-\mathrm{T} 2 \mathrm{r} \_4, \mathrm{~T} 2 \mathrm{r} \_5$, T2_6).
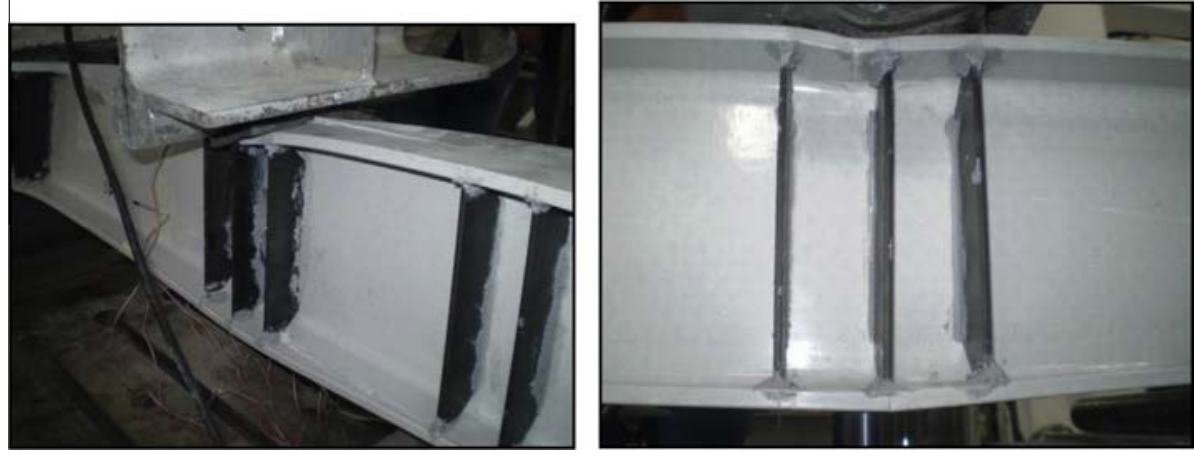

Fig. 9. Local cracks in T1_1. 
Table 3

Test results: Failure load and deflection at midspan.

\begin{tabular}{|c|c|c|c|c|}
\hline \# Beam & & $\begin{array}{l}\text { Failure load, } P \\
\qquad(\mathrm{kN})\end{array}$ & $\begin{array}{c}\text { Deflection at midspan, } \\
v \\
(\mathrm{~mm})\end{array}$ & $\begin{array}{c}\text { Curing } \\
\text { temperature } \\
\left({ }^{\circ} \mathrm{C}\right)\end{array}$ \\
\hline T1_2 & 178 & \multirow{3}{*}{159 (mean value) } & 15.24 & - \\
\hline T1_3 & 167 & & 13.86 & - \\
\hline T1_4 & 132 & & 9.00 & - \\
\hline T2r_1 & 121 & \multirow{2}{*}{113 (mean value) } & 9.06 & 15 \\
\hline T2r_2 & 105 & & 7.87 & 15 \\
\hline T2_3 & 85 & & 7.80 & 15 \\
\hline $\mathrm{T} 2 \mathrm{r} \_4$ & 169 & \multirow{2}{*}{157 (mean value) } & 11.63 & 28 \\
\hline T2r_5 & 144 & & 8.77 & 28 \\
\hline T2_6 & 70 & & 4.04 & 28 \\
\hline
\end{tabular}

- The mechanical response of the Type 2 beams is significantly influenced by the web-flange reinforcement, especially in terms of failure load $P$. Specifically, the failure load decreases from $121 \mathrm{kN}$ (T2r_1) to $85 \mathrm{kN}$ (T2_3) for samples whose curing temperature was kept at $15^{\circ} \mathrm{C}$, while it decreases from $169 \mathrm{kN}$ (T2r_4) to $70 \mathrm{kN}$ (T2_6) for samples whose curing temperature is set at $28^{\circ} \mathrm{C}$.

- Type 2 beams exhibit an excellent performance compared with Type 1 beams in terms of flexural stiffness, while no relevant difference can be observed in terms of failure load.

- The strain profile exhibited by Type 2 beams can be considered almost linear, thus showing that the relative displacements between flange and web panels are negligible.

The good performance of the flexural response of Type 2 beams with respect to Type 1 beams is clearly dependent upon the mechanical properties of the specific adhesive used in the bonding process. In fact, the web-flange junctions are generally a weak zone in pultruded beams, due to the large amount of resin which is typically placed there during the pultrusion process. It is worth noting that mechanical properties of the inner polyester resins are less performing compared to the structural epoxy adhesive considered in this study (SikaDur-30).

Finally, in Fig. 11 the load vs. mid-span flexural deflection curves are reported for all tests, comparing the experimental results with

Table 4

Test results: bending curvature, Young's modulus, flexural mid-span deflection and curing temperature.

\begin{tabular}{|c|c|c|c|c|c|c|}
\hline \# Beam & $\begin{array}{l}\text { Load level } \\
\quad(\mathrm{kN})\end{array}$ & $\begin{array}{l}\text { Cross-section bending curvature, } \theta \\
\qquad \mathrm{mm}^{-1} \times 10^{-4}\end{array}$ & $\begin{array}{l}\text { Web panel bending curvature, } \theta_{w} \\
\qquad \mathrm{~mm}^{-1} \times 10^{-4}\end{array}$ & $\begin{array}{l}\text { Young's modulus, } E \text { (UNI) } \\
\text { (MPa) }\end{array}$ & $\begin{array}{c}v \\
\mathrm{~mm}\end{array}$ & $\begin{array}{l}\text { Curing temperature } \\
{ }^{\circ} \mathrm{C}\end{array}$ \\
\hline \multirow[t]{2}{*}{ T1_2 } & 50 & 9.162 & 9.338 & \multirow[t]{2}{*}{20986} & 3.535 & \multirow[t]{2}{*}{-} \\
\hline & 100 & 17.780 & 18.030 & & 7.038 & \\
\hline \multirow[t]{2}{*}{ T1_3 } & 50 & 8.197 & 9.633 & \multirow[t]{2}{*}{19405} & 4.090 & \multirow[t]{2}{*}{-} \\
\hline & 100 & 15.410 & 18.152 & & 7.854 & \\
\hline \multirow[t]{2}{*}{ T1_4 } & 50 & 7.227 & 9.094 & \multirow[t]{2}{*}{19885} & 2.914 & \multirow[t]{2}{*}{ - } \\
\hline & 100 & 13.710 & 18.361 & & 6.462 & \\
\hline \multirow[t]{2}{*}{ T2r_1 } & 50 & 7.888 & 8.079 & \multirow[t]{2}{*}{18630} & 2.823 & \multirow[t]{2}{*}{15} \\
\hline & 100 & 16.001 & 16.660 & & 6.795 & \\
\hline \multirow[t]{2}{*}{ T2r_2 } & 50 & 7.597 & 6.404 & \multirow[t]{2}{*}{18254} & 3.734 & \multirow[t]{2}{*}{15} \\
\hline & 100 & 14.620 & 12.361 & & 7.453 & \\
\hline T2_3 & 50 & 8.751 & 8.736 & 18072 & 3.976 & 15 \\
\hline \multirow[t]{2}{*}{ T2r_4 } & 50 & 8.652 & 7.892 & \multirow[t]{2}{*}{19810} & 2.689 & \multirow[t]{2}{*}{28} \\
\hline & 100 & 17.280 & 15.790 & & 6.216 & \\
\hline \multirow[t]{2}{*}{ T2r_5 } & 50 & 9.157 & 8.621 & \multirow[t]{2}{*}{22411} & 2.512 & \multirow[t]{2}{*}{28} \\
\hline & 100 & 18.081 & 17.380 & & 5.501 & \\
\hline T2_6 & 50 & 8.667 & 7.895 & 23724 & 2.817 & 28 \\
\hline
\end{tabular}

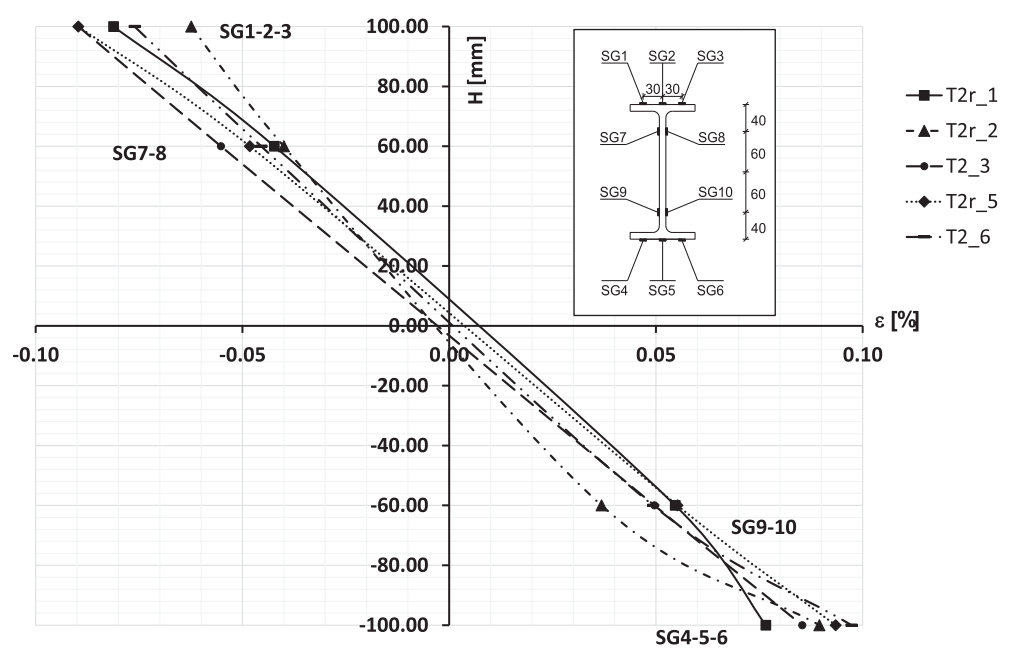

Fig. 10a. Strain profile at mid-span cross-section for bonded beams for load level $50 \mathrm{kN}$. 


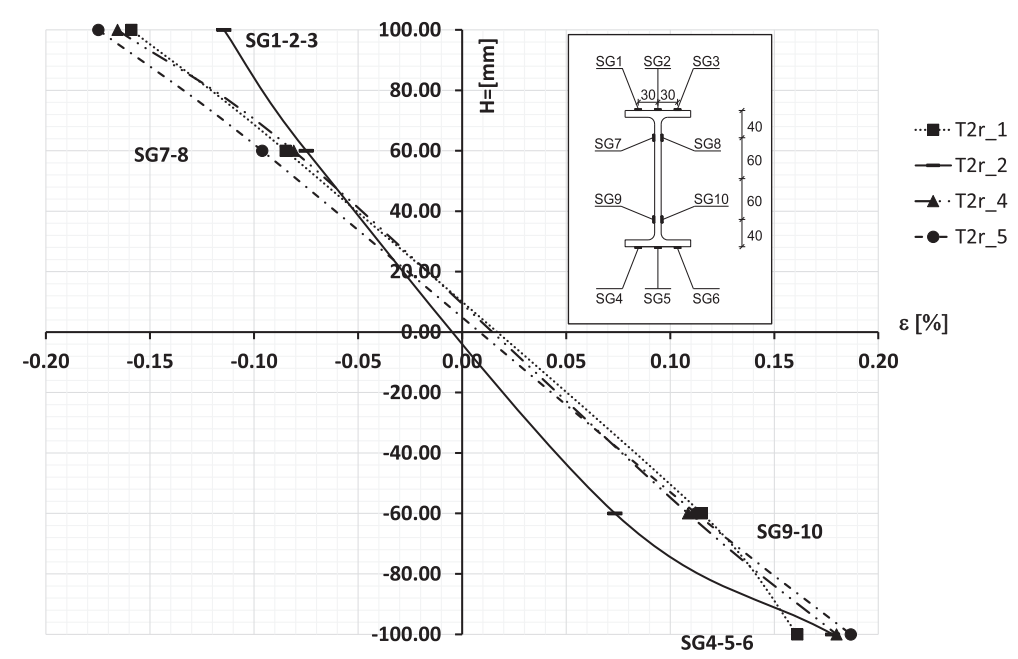

Fig. 10b. Strain profile at mid-span cross-section for bonded beams for load level $100 \mathrm{kN}$.

(a)

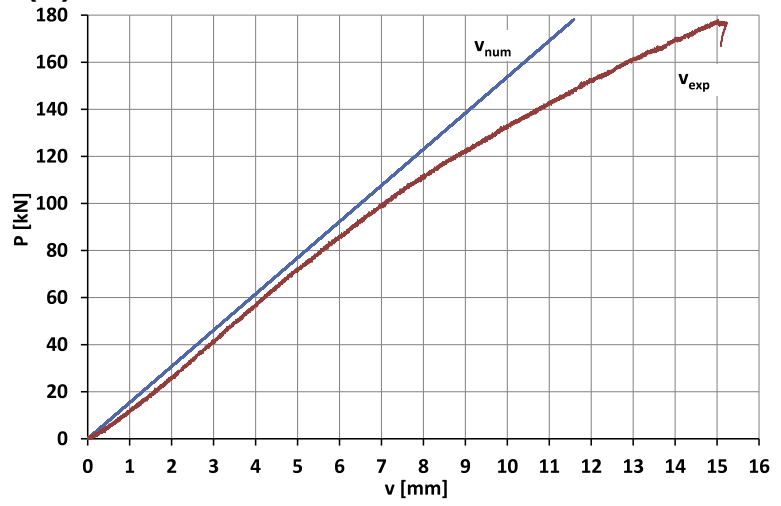

(b)

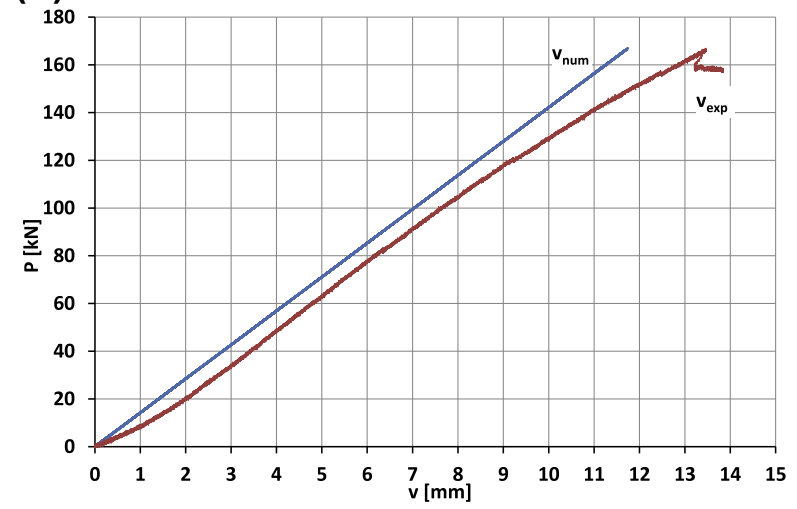

(c)

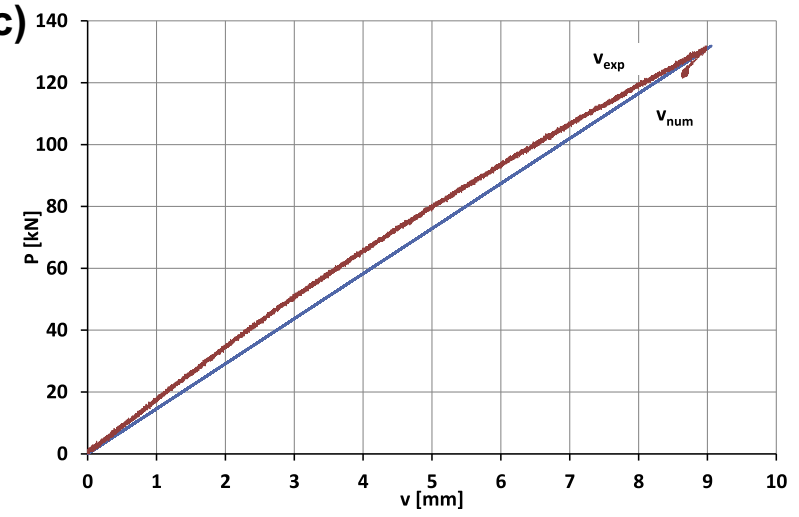

Fig. 11a. Load vs mid-span flexural deflection curve - comparison between experimental and analytical results: (a) T1_2 beam; (b) T1_3 beam; (c) T1_4 beam.

the numerical ones evaluated by Eq. (1). The Young's modulus $E$ is reported in Table 4 while the second moment of area $I$ varies according to the Type 1 and 2 cross-sections. The calculation of the flexural stiffness EI for all beams tested is reported in Table 5.

The second moment of area $I$ for the beams strengthened by adding an adhesive curb at the web-flange junction (T2r_1, T2r_2, T2r_4 and T2r_5) was evaluated by scaling the adhesive curb contribution by means of ratio $\frac{E_{\text {adhesive }}}{E_{\text {GRPP }}}=n\left(E_{\text {adhesive }}=10400 \mathrm{MPa}\right)$.

The curves depicted in Fig. 11 allow the following considerations:
- for all beams tested the analytical solution (linear elastic) allows us to evaluate correctly the experimental mid-span flexural deflections;

- for all Type 1 beams (pultruded) the analytical solution seems to underestimate mid-span flexural deflections, especially near the failure load;

- for all Type 2 beams (bonded) the analytical solution seems to slightly overestimate mid-span flexural deflections, especially for load levels equal to $50 \%$ of the failure load. 
(a)

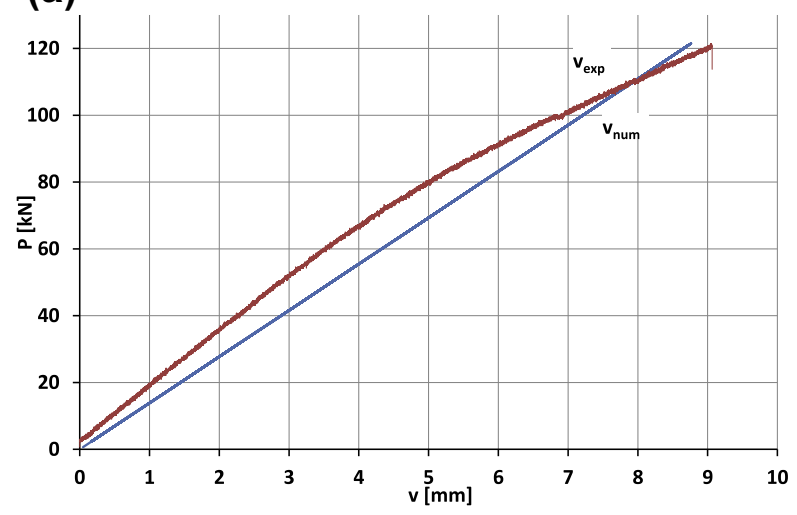

(b)

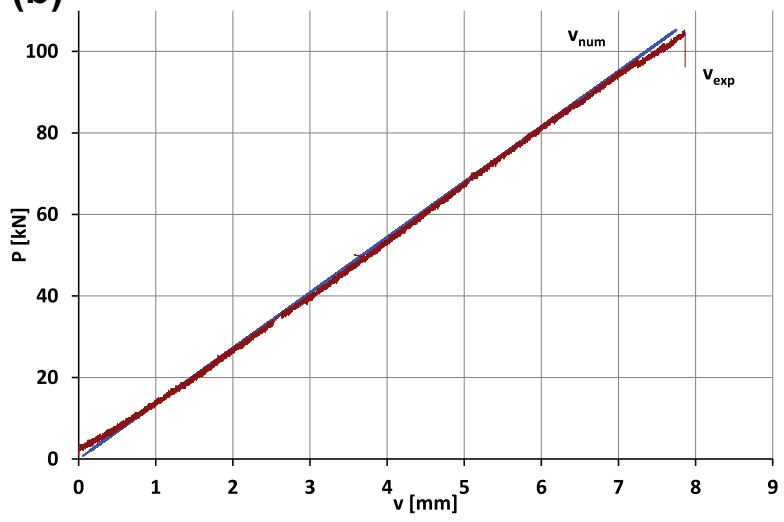

Fig. 11b. Load vs mid-span flexural deflection curve-comparison between experimental and analytical results: (a) T2r_1 beam; (b) T2r_2 beam.

(a)

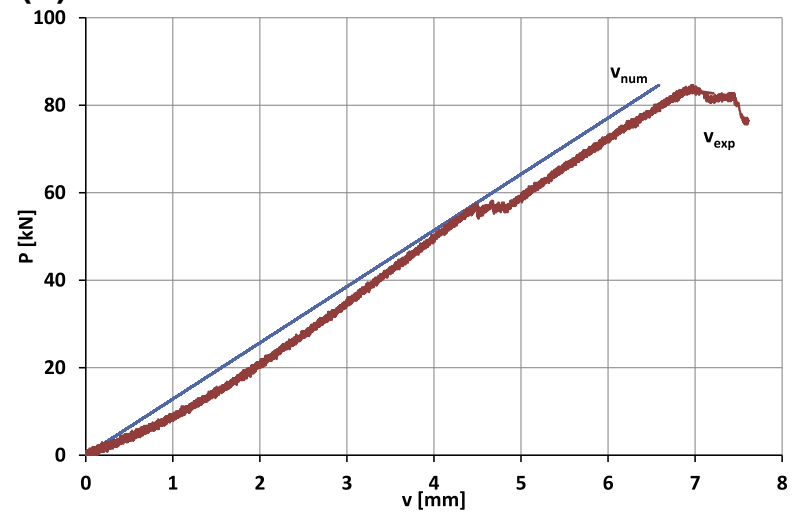

(b)

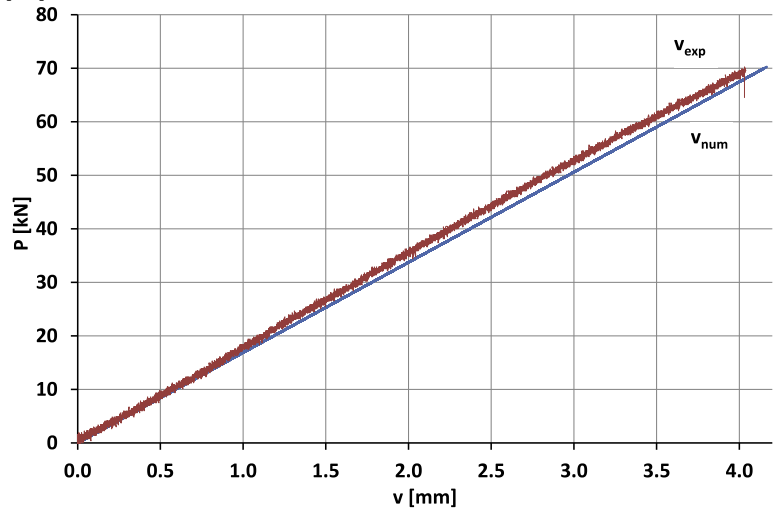

Fig. 11c. Load vs mid-span flexural deflection curve - comparison between experimental and analytical results: (a) T2_3 beam; (b) T2_6 beam.

(a)

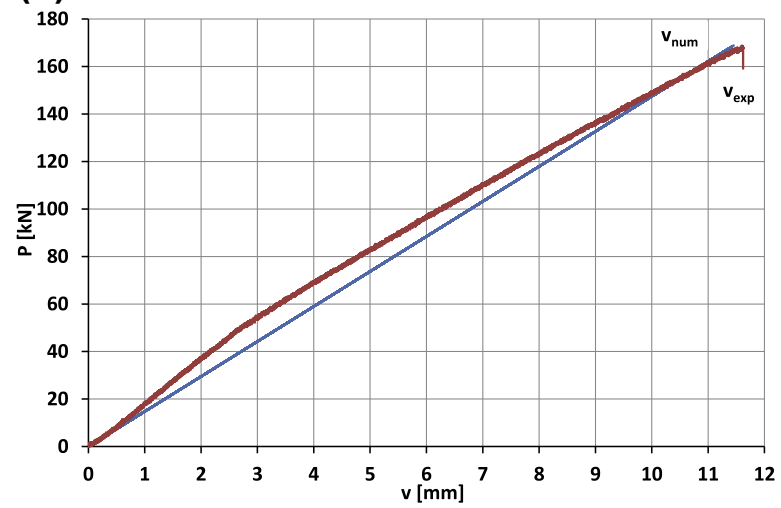

(b)

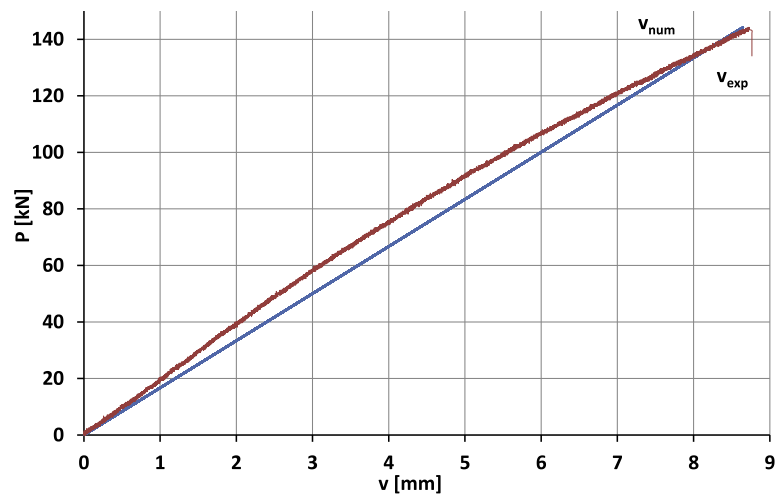

Fig. 11d. Load vs mid-span flexural deflection curve - comparison between experimental and analytical results: (a) T2r_4 beam; (b) T2r_5 beam.

\section{Conclusions}

In this paper an experimental campaign was developed in order to evaluate the flexural response of beams created by bonding simple GFRP panels together. The idea of studying this new paradigm of beams is focused on the possibility of achieving complex FRP shapes by means of low-cost designs inspired by modularity. The results obtained now permit us to answer the two questions posed in the introduction.
The first was "what performance level can be achieved for bonded composite beams compared to similar pultruded ones?".

Considering the experimental results obtained, it is possible to conclude that bonded beams are characterised by an equivalent failure load and by a stiffness higher than classical pultruded beams, especially at the serviceability limit state.

The second question was "can the loss of stiffness, due to the bonding, affect the pre-failure response and the failure loads of bonded beams?". 
Table 5

Flexural stiffness evaluation.

\begin{tabular}{|c|c|c|c|}
\hline $\begin{array}{l}\# \\
\text { Beam } \\
\end{array}$ & $\begin{array}{l}\text { Young's modulus, E } \\
\text { (UNI) (MPa) }\end{array}$ & $\begin{array}{l}\text { Second moment of } \\
\text { area } I\left(\mathrm{~mm}^{4}\right)\end{array}$ & $\begin{array}{l}\text { Flexural stiffness EI } \\
\left(\text { N.mm }{ }^{2}\right)\end{array}$ \\
\hline T1_2 & 20986 & $23^{\prime} 600^{\prime} 000$ & $495^{\prime} 268^{\prime} 260^{\prime} 932$ \\
\hline T1_3 & 19405 & $23^{\prime} 600^{\prime} 000$ & $457^{\prime} 953^{\prime} 523^{\prime} 397$ \\
\hline T1_4 & 19885 & $23^{\prime} 600^{\prime} 000$ & $469^{\prime} 278^{\prime} 019^{\prime} 579$ \\
\hline T2r_1 & 18630 & $23^{\prime} 973^{\prime} 454$ & $446^{\prime} 628^{\prime} 863^{\prime} 414$ \\
\hline T2r_2 & 18254 & $23^{\prime} 973^{\prime} 454$ & $437^{\prime} 600^{\prime} 031^{\prime} 850$ \\
\hline T2_3 & 18072 & $22^{\prime} 900^{\prime} 000$ & $413^{\prime} 854^{\prime} 294^{\prime} 746$ \\
\hline T2r_4 & 19810 & $23^{\prime} 973^{\prime} 454$ & $474^{\prime} 914^{\prime} 760^{\prime} 286$ \\
\hline T2r_5 & 22411 & $23^{\prime} 973^{\prime} 454$ & $537^{\prime} 257^{\prime} 265^{\prime} 380$ \\
\hline T2_6 & 23724 & $22^{\prime} 900^{\prime} 000$ & $510^{\prime} 764^{\prime} 803^{\prime} 209$ \\
\hline
\end{tabular}

Differences in flexural mechanical behaviour were observed between the two types of bonded beams tested. The first configuration corresponds to a beam with no reinforcement at the webflange connection and the second one to a beam strengthened at the same connection with a curb of epoxy resin. The reinforcement plays an important role in contrasting the torsional rotations between the web and flange because a decrease of mechanical response was observed for non-reinforced bonded beams. Furthermore, it is possible to conclude that the connection reinforcement is a better way to contrast the rotational effects than the rounded web-flange connection typical of the pultrusion process.

As a first perspective, the authors intend to study in detail the role played by the web-flange connection in flexural mechanical behaviour by considering different epoxy resins, the geometry of the connection, quality of the bonding surfaces (roughness, chemical treatment, etc.), and the possible reinforcement with other GFRP parts instead of epoxy resin curb. Moreover, different beam slenderness and cross-section geometries as well as load conditions will be considered.

A second perspective is to characterise more precisely the bonding interfaces, as proposed in [20], in order to provide the parameters needed to perform numerical simulation (material properties and cohesive zone model).

The final aim will be to develop a numerical 3D model. The first step will be to compare the numerical results with the experimental ones in order to predict the flexural behaviour of the bonded beams. The second step will consist in optimising the way to bond simple GFRP panels together by using numerical modelling results in order to obtain a better mechanical flexural response.

\section{Acknowledgement}

The Italian Department of Civil Protection (DPC) provided financial support for this research (project ReLuis 2015).

\section{References}

[1] Hollaway LC. Applications of fibre-reinforced polymer composite materials. ICE Manual of Construction Materials: Polymers and Polymer Fibre Composites. London: Thomas Telford Limited; 2010. pp. 109-127.

[2] Bank LC. Composites for Construction-Structural Design with FRP Materials. New Jersey: John Wiley \& Sons; 2006.

[3] Halliwell SM. Polymer Composites in Construction, BRE/DETR UK, BR405. UK: Building Research Establishment; 2000.

[4] Borri A, Castori G, Corradi M, Speranzini E. Durability analysis for FRP and SRG composites in civil applications. Key Eng. Mater. 2015;624:421-8.

[5] L. Zhao, R. Burguono, H.L. Rovere, F. Seible , V. Karbhari. Preliminary evaluation of the hybrid tube bridge system. Technical Report No TR-2000/4-59A0032, California Department of Transportation. 2000.

[6] E.J. Guades, T. Aravinthan, M.M. Islam. An overview on the application of FRP composites in piling system. Southern Region Engineering Conference 2010, SREC 2010; 65-70.

[7] Gabor A, Bennani A, Jacquelin E, Lebon F. Modelling approaches of the in-plane shear behaviour of unreinforced and FRP strengthened masonry panels. Compos. Struct. 2006;74(3):277-88.

[8] UNI EN ISO 13706-3:2002. Reinforced plastics composites. Specifications for pultruded profiles. Part 3: Specific requirements.

[9] Kollár LP, Springer GS. Mechanics of Composites Structures. Cambridge University Press; 2003.

[10] Barbero EJ. Introduction to Composite Material Design. Philadelphia: Taylor \& Francis; 1998.

[11] Mancusi G, Feo L. Non-linear pre-buckling behavior of shear deformable thinwalled composite beams with open cross-section. Compos. Part B: Eng. 2013;47:379-90.

[12] Ascione L, Berardi VP, Giordano A, Spadea S. Local buckling behavior of FRP thin-walled beams: a mechanical model. Compos. Struct. 2013;98:111-20.

[13] Ascione L, Berardi VP, Giordano A, Spadea S. Macro-scale analysis of local and global buckling behavior of T and C composite sections. Mech. Res. Commun. 2014;58:105-11.

[14] Ascione L, Berardi VP, Giordano A, Spadea S. Pre-buckling imperfection sensitivity of pultruded FRP profiles. Compos. Part B: Eng. 2015;72:206-12.

[15] Ascione F, Mancusi G. The influence of the web-flange junction stiffness on the mechanical behaviour of thin-walled pultruded beams. Compos. Part B: Eng. 2013;55:599-606.

[16] Ascione F. Influence of initial geometric imperfections in the lateral buckling problem of thin walled pultruded GFRP I-profiles. Compos. Struct. 2014;112:85-99.

[17] Mancusi G, Ascione F, Lamberti M. Pre-buckling behavior of composite beams: a mechanical innovative approach. Compos. Struct. 2014;117:396-410.

[18] Turvey GJ, Zhang Y. A computational and experimental analysis of buckling, post buckling and initial failure of pultruded GRP columns. Comput. Struct. 2006;84:1527-37.

[19] Davalos JF, Qiao P, Salim HA. Flexural-torsional buckling of pultruded fiber reinforced plastics composite I-beams: experimental and analytical evaluations. Compos. Struct. 1997;38:241-50.

[20] Cocheteau N, Maurel-Pantel A, Lebon F, Rosu I, Prieto E, Ait-Zaid S, Savin de Larclause I, Salaun Y. Process parameters influence on mechanical strength of direct bonded surfaces for both materials: silica and Zerodur ${ }^{\circledR}$ glasses. J. Adhes. Sci. Technol. 2014;28(10):915-34. 